\title{
Strategies adopted by parents in the schooling experi- ence of their young and adult children with disabilities
}

\author{
Estratégias adotadas pelos pais na vivência da escolarizaçáo de filhos adultos e crianças \\ com deficiência \\ Estrategias adoptadas por los padres en la escolarización de hijos adultos y niños con \\ discapacidad
}

Hilda Rosa Moraes de Freitas Rosário*; Simone Souza da Costa e Silva**

\begin{abstract}
Background: People diagnosed with intellectual or multiple disabilities and their families have specific needs, and the support offered by professionals is a way to mitigate the effects of excluding practices, particularly in school settings. Objectives: To identify parents' actions/interactions and constraints concerning their experience of the schooling process of their children with disabilities, and contribute to the planning of interventions with parents.

Methodology: The Grounded Theory (GT) was used. Nine parents were interviewed using a semi-structured guide.

Results: The core category Experiencing the schooling process of children with disabilities: between school exclusion, inclusion and integration was composed of 3 macro-categories: The school world for students with disabilities (conditions), Parental strategies on their children's schooling process (action/interaction), and Results of parents' experience of their children's schooling process (consequences).

Conclusion: The use of GT allowed understanding the impact of parents' strategies on their children's academic path. Many of these parents moved their children to another school, enrolling them in specialized institutions, while others removed the children from the school environment to ensure the achievement of their developmental goals.
\end{abstract}

Keywords: parents; grounded theory; special education; disabled persons

\section{Resumo}

Enquadramento: Os diagnósticos de deficiência intelectual ou múltipla trazem necessidades à pessoa e à família, sendo 0 apoio oferecido pelos profissionais uma forma de atenuar os efeitos das práticas excludentes, sobretudo no contexto escolar. Objetivos: Identificar as ações/interações dos pais e seus condicionantes, ao vivenciarem a escolarização do filho com deficiência e contribuir para o planeamento de intervenções com os pais.

Metodologia: Adotou-se a metodologia da Grounded Theory (GT). Foram entrevistados 9 pais, a partir de um roteiro semiestruturado.

Resultados: A categoria central foi Vivenciar a escolarização do filho com deficiência: entre a exclusão e a inclusão, escolar composta de três macrocategorias: $\mathrm{O}$ mundo da escola para alunos com deficiência (condições), Estratégias dos pais diante da escolarização do filho (ação/interação) e Resultados da vivência da escolarização do filho (consequências).

Conclusão: Aplicar a GT permitiu compreender os efeitos das estratégias dos pais na trajetória escolar dos seus filhos. Muitos mudaram os seus filhos de escola, matriculandoos em instituições especializadas, outros tiraram-nos do ambiente escolar, para que alcançassem os objetivos para 0 desenvolvimento dos filhos.

Palavras-chave: pais; teoria fundamentada nos dados; educação especial; pessoas com deficiência * MSc., Student, Federal University of Pará, 66075-110, Brazil [hildarosamf@gmail.com]. Address for
correspondence: Tv. Barão do Triunfo n'3508, apto. 2105, Edifício Uno Tower. Bairro: Marco, 666095-
050, Pará, Brasil. Contribution to the article: literature search, data collection and analysis, article writing
** Ph.D., Adjunct Professor III, Federal University of Pará, 66075-110, Brazil [symon.ufpa@ @gmail.com] Contribution to the article: data analysis and discussion.

\section{Resumen}

Marco contextual: El diagnóstico de discapacidad intelectual o múltiple supone una serie de necesidades para la persona y la familia. Por ello, el apoyo ofrecido por los profesionales se convierte en una forma de mitigar los efectos de las prácticas de exclusión, particularmente en el contexto escolar.

Objetivos: Identificar las acciones/interacciones de los padres y sus condicionantes al vivir la escolarización del hijo con discapacidad, y contribuir a la planificación de intervenciones con los padres.

Metodología: Se adoptó la Teoría Fundamentada en los Datos (TDF) y se entrevistó a 9 padres, para lo cual se utilizó una guía semiestructurada.

Resultados: La categoría central fue Vivir la escolarización del hijo con discapacidad: entre la exclusión y la inclusión escolar, compuesta de 3 macrocategorías: El mundo de la escuela para alumnos con discapacidad (condiciones); Estrategias de los padres ante la escolarización del hijo (acción/interacción), y Resultados de la vivencia de la escolarización del hijo (consecuencias).

Conclusión: aplicar la TFD permitió comprender los efectos de las estrategias de los padres en la trayectoria escolar de sus hijos. Muchos cambiaron a sus hijos de escuela y los matricularon en instituciones especializadas, otros los sacaron del ambiente escolar para que alcanzasen sus objetivos de desarrollo.

Palabras clave: padres; teoría fundamentada; educación especial; personas con discapacidad

Received for publication: 13.09 .16

Accepted for publication: 21.11.16 


\section{Introduction}

According to the American Association on Intellectual and Developmental Disabilities (American Association on Intellectual and Developmental Disabilities [AAIDD], 2010), intellectual disability (ID) is a condition of disability characterized by significant limitations both in intellectual functioning and in adaptive behavior, whose symptoms start before the age of 18 .

The first definitions of ID, formerly known as mental retardation, mental deficiency, among others, have identified it as a limitation of the person, without an association with the environment. Although it is seen as a product of the interaction between aspects inherent to the individuals and aspects related to their physical and social environment since 1992 (Verdugo \& Jenaro, 2014), the idea that ID is a characteristic of an individual is still present in the relatives' and professionals' perspective, even if veiled (Lima \& Mendes, 2011; Schmidt \& Angonese, 2009).

Furthermore, people with multiple disabilities are diagnosed with a limited cognitive function associated with motor and/or sensory limitations (Rocha \& Pletsch, 2015). And, in this case, "it is not the sum of these changes that characterize multiple disabilities, rather it is the level of development, the functional, communication, social interaction, and learning possibilities that determine the educational needs of these individuals" (Monte \& Santos, 2006, p.11).

In this way, the diagnosis of a disability is a key moment, both for the development of the person being diagnosed and for the history of the family as a whole. In their analysis of quantitative data from a questionnaire applied to two groups (one with 24 caregivers of children with cerebral palsy, and another one with 32 caregivers of children without disabilities), Fernandes, Vale, Nóbrega, Dias, and Sousa (2012) found that the caregivers in the first group felt more supported by professionals in general $(M=3.8 ; S D$ $=0.9$ ), while the caregivers in the second group reported that they received this support from family members $(M=3.2 ; S D=0.7)$.

In the case of elderly caregivers of adults with disabilities, this need for social support becomes even more evident. Martins and Couto (2014) interviewed five elderly parents of adults with disabilities and found that they lived in social isolation due to their children's care needs related to self-care, guidance, and transportation, as well as activities of daily living. Although nursing research studies address care delivery to children with physical or developmental limitations (Martins, Abreu, \& Figueiredo, 2014), there are yet few studies on the nurses' interventions toward both the caregivers of children with disabilities (Fernandes et al., 2012) and caregivers of adults with disabilities. Thus, this study aimed at identifying the actions/interactions and constraints of parents (father or mother) in their experience of the schooling process of their children with intellectual or multiple disabilities in basic education. In particular, this study aimed to contribute to the planning of nursing interventions with the parents/caregivers of school-aged young and adult children with disabilities, since parents need to reconcile their daily needs with their children's school activities and therapeutic care.

\section{Background}

According to Pletsch (2014a), the growing number of legal devices that organized and guided school practices for the process of school inclusion led to a gradual increase in the number of students with disabilities enrolled in the regular education network. In a study with 24 relatives of students with ID aged between 9 and 29 years, of whom a third were illiterate, Lima, and Mendes (2011) identified the following parents' reasons for enrolling their children in regular school: first, learning and development in general; second, socialization; and third, literacy.

These relatives pointed out the following contributions of the school to the student's life: specialized educational assistance (atendimento educacional especializado - AEE), followed by literacy, and socialization. AEE is a service that is planned and implemented to complement regular education, but these relatives see it as reinforcement to curricular activities and/or therapeutic support; thus, it is mentioned as a more positive aspect in the student's development when compared to literacy and socialization (Lima \& Mendes, 2011).

It should be noted that many parents, and even teachers, still have difficulty in recognizing the practices of regular education schools as promoters of the development of students with disabilities. Silveira and Neves (2006) interviewed 10 families and 10 teachers of children with disabilities and found that 
the participants questioned the benefits of including these students in regular classes, often due to the lack of structures in public schools to meet their learning needs.

Pletsch (2014a, 2014b) found similar results about the AEE service and the low literacy rates of the special education population since "students with more severe or multiple disabilities, despite being enrolled in regular education, end up attending the multifunctional resource room for only one hour, two or three times a week" (Pletsch, 2014a, p. 17), i.e., they only attend AEE.

After analyzing interviews with teachers and school administrators and footage of the pedagogical practices applied in AEE rooms, Pletsch (2014b) concluded that many students with ID ended up being sent to youth and adult education classes (type of education for students who, for whatever reason, have not completed basic and/or secondary education within the appropriate age) after years in regular classes without learning how to read and write. Although literacy was one of the reasons for enrolling the student with ID in school, and referred to as being a contributing factor by the participants in the study of Lima and Mendes (2011), it remains a reality distant from this population, as pointed out in several studies. Schmidt and Angonese (2009) interviewed 20 adults with ID aged between 19 and 35 years working at a supermarket. According to their accounts, the school was the place of discovery of their disability to the extent that it was there that the difficulties in learning the contents, reading and writing first emerged. Many of them have associated their history of school failure with their disability, considering themselves to be the cause for their difficulties, without considering aspects related to their schools' organization and structure.

Maturana and Cia (2015) analyzed 20 studies (nine theses and 11 dissertations) on the partnership between the family and school of students with disabilities enrolled in regular education, and found that, in some of these studies, parents reported that their children with disabilities had learned no school contents. In general, families assessed their children's school inclusion process as negative and associated the lack of investment in the school environment with the discredit of the professionals working there and the development ability/potential of students with disabilities.

\section{Research Questions}

Family engagement in the schooling process of children with disabilities is considered as a complex phenomenon, since it involves the negotiation of meanings in the interaction between parents and children, and between the latter and the school, in a specific time and place. Therefore, we formulated the following guiding question for this study: What are the parents' actions/interactions and constraints in their experience of the schooling process of their children with intellectual or multiple disabilities in basic education?

\section{Methodology}

This study adopted a qualitative approach based on the Grounded Theory (GT) methodology, from the perspective of Strauss and Corbin (2008). According to the GT, data collection and analysis must occur simultaneously using a systematic, detailed, constant, and spiral process of data gathering, coding, and analysis through an inductive (in which codes, categories, and corresponding relationships emerge based on data) and deductive movement (testing data through comparisons between them, and between them and other data; Flick, 2009).

As a result, theoretical sampling was not based on a specific number of participants; instead, it started with the collection of data from a specific group - parents of adults with disabilities (Group I). Then, during data analysis, and with the purpose of adding more consistency to the categories, parents of children with disabilities (Group II) were interviewed. These parents were selected based on the following criteria: having a child with intellectual or multiple disabilities who participated in animal-assisted activities within the scope of the EntreLaço program.

We used an interview guide divided into two parts: I - Demographic data with eight closed-ended questions; and II - Specific questions with three open-ended questions, starting with the following question What does it mean for you to have a child with a disability? The insertion of new topics in the interview depended on the pace, content, and pauses of the participants' accounts. Questions on two other aspects were also asked: the changes resulting from their children's diagnosis/birth ("What changed with 
your children's birth/disability diagnosis?"), and their expectations for their own future and the future of their children with a disability ("What are your expectations for your child's and your own future?". Although the guide included no questions about their children's schooling process, the participants recalled during the interview the whole process of diagnosis of disability and its treatment, and also talked about the academic path of their children with disabilities, which is the object of analysis in this study.

The category presented here and identified as a phenomenon is part of a broader analysis on the parenthood phenomenon among parents of people with disabilities.

Initially, we contacted the general coordinators of the EntreLaço program, who approved the development of the study. This program is developed by a higher education institution (HEI) in the city of Belém (Pará, Brazil) and its main purpose is to assist in the biopsychosocial development of young and adult people with disabilities through activities performed with animals as co-therapists and/or motivators.

As a result, we identified the parents whose children participated in the program activities and who met the Inclusion criteria. In order to protect the identity of participants and their children, we identified them as follows: parents - P1 to P9, and children - C1 to C9. During data collection, none of the participants withdrew from the study. The interviews were conducted in a location chosen by the parents (a room of the EntreLaço program or their homes). In general, the interviews lasted between 40 and 50 minutes. It should be noted that data were collected between August 2015 and June 2016, and that the theoretical saturation for the relevant concepts was reached with the nine interviews.

After each interview, the contents were transcribed and analyzed without the use of software. In the open coding process, we performed a microanalysis, in which the contents of the statements were initially coded line by line so that the researcher could become familiarized with the data, and then analyzed by identifying events based on: questions such as "What is going on here?", and theoretical comparisons of concepts for each participant, between participants, and with the memoranda drawn up along the process. Our aim was to isolate a paragraph or follow-up (code), and identify it for later classification based on its properties and dimensions.
In the axial coding process, we classified and organized the links that emerged between categories, identifying the causes and conditions for the phenomenon occurrence (its structure), the actions or strategies implemented by the participants (the process), and the results or consequences of these actions. Then, based on this organization, the plot for the definition of the core category was elaborated in the selective coding process. It should be noted that these data were presented to three participants (P1, $\mathrm{P} 4$, and $\mathrm{P} 5$ ) in the data validation phase.

This study complied with the ethical principles and legal implications of Resolution no. 196/1996 of the National Health Council/Ministry of Health of Brazil. Data collection began only after the approval of the Research Ethics Committee of the Department of Tropical Medicine of the Federal University of Pará (Opinion no. 1.125.916). All participants of the study signed an Informed Consent Form (ICF).

\section{Results and discussion}

The mean age of the participants in Group I was $M$ $=53.66$ years, $S D=8.71$. With regard to the level of education, most of them had completed secondary education $(N=3)$. Family income ranged between one to two minimum wages and two to three minimum wages ( $N=3$ in each income range). Four of the six participants had a spouse and two had no partner. In regard to occupation, two participants had a paid activity and four were housewives. This group was composed of five mothers and one father. The mean age of the participants in Group II was $M=41$ years, $S D=9.53$. As to education, two of them had completed higher education and had a regular paid employment. This group was composed by three mothers, each in a different family income range: income of one to two minimum wages; income of two to three minimum wages; and income of five to 10 minimum wages. The two mothers with lower income were single, and the mother with higher family income was married.

The microanalysis of the transcripts resulted in several codes, which, when grouped by means of an inductive analysis, generated 39 provisional categories in the open coding process. These categories were regrouped, based on their properties and dimensions, into 25 categories which were considered to be 
subcategories of the three macro-categories identified through the paradigm components (condition, action/interaction, and consequences) in the axial coding process.

This data analysis resulted in three macro-categories: The school world for students with disabilities, Parental strategies on their children's schooling process, and Results of parents' experience of their children's schooling process. These macro-categories, and corresponding subcategories, constitute the phenomenon Experiencing the schooling process of children with disabilities: between school exclusion, inclusion and integration (Figure 1).

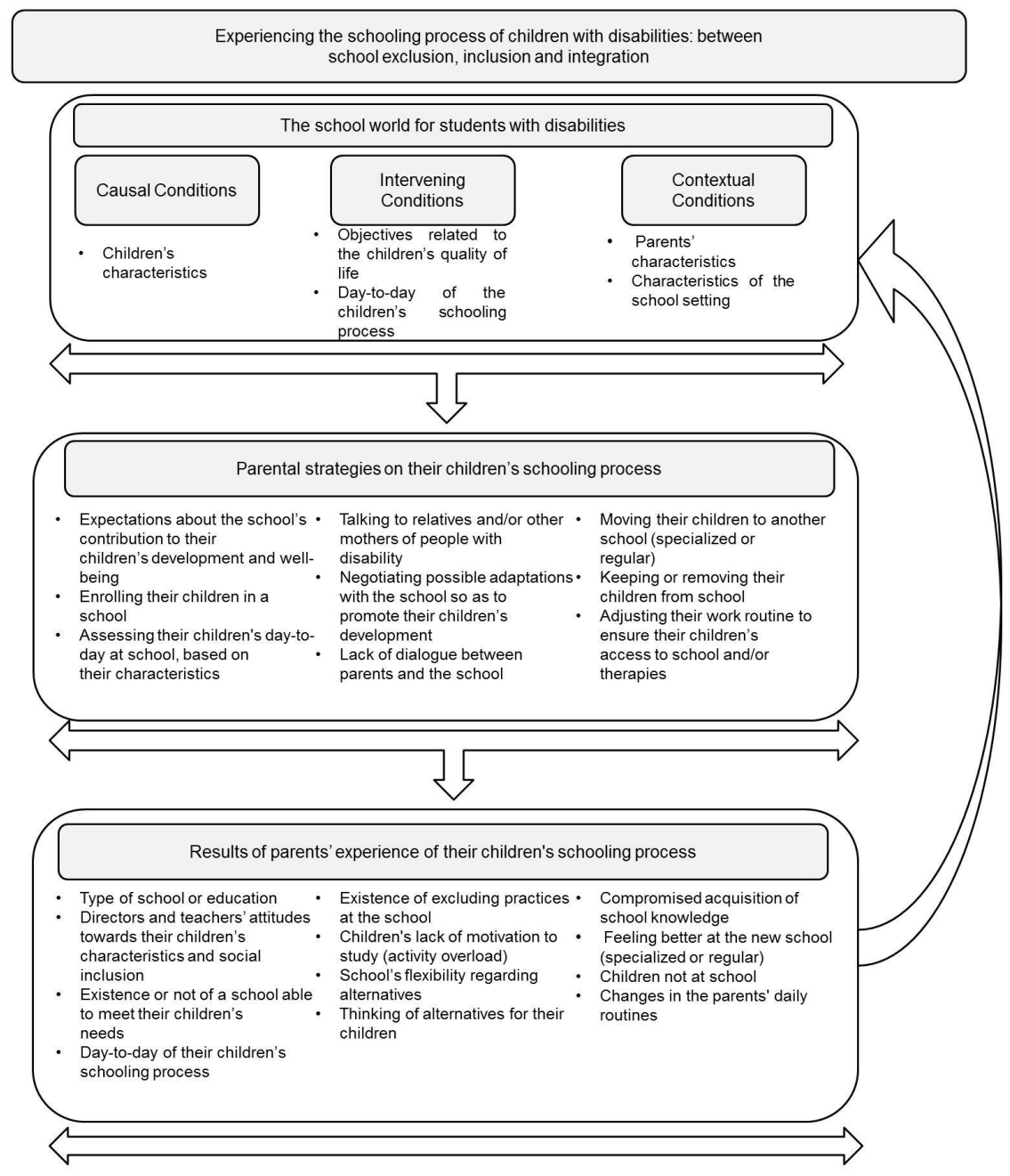

Figure 1. Composition of the phenomenon Experiencing the schooling process of children with disabilities: between school exclusion, inclusion and integration.

The structuring conditions of the phenomenon Experiencing the schooling process of children with disabilities: between school exclusion, inclusion and integration were grouped under the macro-category The school world for students with disabilities. This macro-category includes the children's characteristics as causal conditions; the objectives related to the children's quality of life and the day-to-day of the children's schooling process as intervening conditions; and the parents' characteristics and the characteristics of the school setting as contextual conditions, all interacting with each other and guiding the parents' actions/interactions, both at a micro (the actions and reflections of this father/mother) and macro level (the parent's actions/interactions with members of the nuclear or extended family and school personnel).

The actions/interactions identified in the parents' accounts constitute the category Parental strategies 
on their children's schooling process and its consequences (i.e., the progressive action over time between condition and action/interaction) are part of the category Results of parents' experience of their children's schooling process. Initially, the school world for students with disabilities was composed of aspects related to parents, rather than the aspects related to the school or the children. The criteria that guided the parents' initial strategies were based on the relationship between three subcategories: Parents' characteristics, Child's characteristics, and Objectives related to the children's quality of life. The subcategories Day-to-day of the children's schooling process, and Characteristics of the school settings emerged as the phenomenon was being outlined based on the actions/interactions and consequences. The latter contributed to the phenomenon of Experiencing the schooling process of children with disabilities: between school exclusion, inclusion and integration.

The parents' characteristics involved in their strategies towards the integration of children with disabilities at school were: 1) insufficient information and knowledge about their children's diagnosis and rights at school; 2) adaptation to their children's disability; and 3) the extent to which parents were able to cope with their children's care needs (constant medical visits and rehabilitation sessions) and reconcile them with their day-to-day routines (work, caring for other children, family's financial conditions, presence/ absence of support, etc.)

The support needs mentioned by these parents were also present in the accounts of the parents of children diagnosed with cerebral palsy (Fernandes et al., 2012) and of elderly parents of adults with disabilities (Martins \& Couto, 2014). We believe that the interventions designed by the school and health professionals, such as nurses, should consider these factors in supporting parents' in order to meet their needs and provide care to their children.

The subcategory Children's characteristics included the concepts related to the parents' perceptions of their children, their limitations (or impairment) and skills (or interests) - to what extent parents perceive their children beyond the diagnosis of ID or multiple disabilities. In other words, to what extent parents understand that this condition is not exclusively based on their children's characteristics, but mainly in the interaction between these characteristics and the environment (Verdugo \& Jenaro, 2014).
In the subcategory Objectives related to the children's quality of life, several concepts were identified, which were grouped under three aspects: cognitive development, physical rehabilitation, or socialization. It should be emphasized that these aspects influenced the category Parental strategies on their children's schooling process, limiting the impact of causal conditions.

P1's account focused on the objectives for her child's cognitive development: "sometimes I argue with him, he needs to know the difference between sugar and flour, he needs to know the difference between sugar and salt, he switches everything, and the change, people keep his change." (P1 - 41 years old, mother of $\mathrm{F} 1$ who was 20 years old and had ID, interview held on 24 August 2015). Although this category also considers goals related to rehabilitation, the goals related to the school setting (cognitive development and socialization) are similar to the reasons which led the parents in the study of Lima and Mendes (2011) to enroll their children with ID in regular school.

These conditions created the context for parents to develop their expectations towards the school's contribution to their children's development and well-being, and to enroll them in a school (special or regular education, in a public or private school). These actions characterized the onset of the category Parental strategies on their children's schooling process, as shown in Figure 1.

When enrolling their children in regular schools, parents were faced with the directors and teachers' attitudes towards their children's characteristics. They view these children's characteristics as inconsistent with the school, therefore requiring a different school, as seen in P3's account: "He was sent for inclusion, but it didn't work out. I talked to the teacher and she said: '-You have to take him to a specialized school' . .. In that school, there was a teacher for 32 students. So I took him out." (P3 - 51 years old, mother of F3 who was 31 years old and had multiple disabilities physical disability associated with ID, interview held on 14 January 2016). These data are similar to those of Schmidt and Angonese (2009), who reported that, in addition to school failure, students with ID and their relatives experienced social exclusion, since the regular school established where they should be, i.e. in special classes/special schools, instead of regular schools.

Other parents, based on their children's accounts and 
their own observations, identified aspects related to the day-to-day of their children's schooling process. Initially, subcategory integrated the phenomenon as an outcome of the parents' strategies but, over time, it became an intervening condition. In addition, the results related to the type of school or education, the directors and teachers' attitudes towards their children's characteristics and social inclusion, and the existence or not of a school able to meet their children's needs contributed to the subcategory Characteristics of the school setting, which is a contextual condition that influenced parents' strategies.

As an intervening condition, the subcategory Day-to-day of the children's schooling process included not only aspects that parents believed to promote their children's inclusion in school, through the stimulation of peer socialization and the teacher's dedication, but also aspects that hindered school inclusion (bullying by students with typical development, lack of motivation to study, isolation in the classroom, etc.). The actions focused on parents' reflections based on their personal life experiences and child care, since the school was not yet a reality in the life of their children with disability, gradually included products from the interaction between the parents and members of the extended family (about the children's school) and new social actors as part of the Characteristics of the school setting (teachers, school directors, and other mothers of students with disabilities, with similar age or diagnosis). Thus, new interventions emerged in the category Parental strategies on their children's schooling process, such as: assessing their children's day-to-day at school based on their characteristics; talking to relatives and/or other mothers of people with disability; negotiating possible adaptations with the school so as to promote their children's development; and lack of dialogue between parents and the school.

P2, whose goal of quality of life for his daughter was related to physical rehabilitation (balance, gait, trunk control, etc), reported that he enrolled her only once at school "because F2's follow-up is stimulation" (P2 - 55 years old, father of $\mathrm{F} 2$ who was 25 years old and had multiple disabilities - physical disability associated with ID, interview held on August 25 2015). This was also reported by $\mathrm{P} 9$, whose daughter also had multiple disabilities. The category The school world for students with disabilities was characterized by adverse, rather than enabling, learning conditions, as seen in P9's account: "She (the daughter) did not attend that specialized school every day, she went once, twice a week, depending on when her teacher was there." (P9 - 31 years old, mother of $\mathrm{F} 9$ who was 10 years old and had multiple disabilities - physical disability associated with ID, interview held on 1 April 2016). When faced with the conditions offered to their daughters, these parents' initial strategy was the lack of dialogue, which made them remove their daughters from school without enrolling them in another school, and to think of alternative activities for their daughters.

This led to new results about parents' experience of the children's schooling process: positive (thinking of alternatives for their children, and the school's flexibility regarding alternatives) and negative (their children's lack of motivation to study - activity overload) results, the existence of excluding practices at the school, and compromised acquisition of school knowledge). The latter two consequences were also identified by Maturana and Cia (2015), Pletsch (2014b) and Silveira and Neves (2006) in their studies. Most parents reported negative results in the initial attempt to integrate their children in school. These results, in turn, brought new conditions to the phenomenon, both in the subcategory Characteristics of the school setting, and in the subcategory Day-to-day of the children's schooling process.

In the case of P1, the action - lack of dialogue between parents and the school-affected her child's academic performance: "he had to do a math test and instead of talking with the teacher from the resource room, no one informed her that she could stay in the room, so he couldn't to the test" (P1 - 41 years old, mother of F1 who was 20 years old and had ID, interview held on 24 August 2015). This P1's and the school's attitudes combined resulted in excluding practices, carried out both by the teachers working with the student and the school directors, thus becoming an intervening condition incorporated into the Day-to-day of the children's schooling process that intensified the limiting factors related to the Children's characteristics for the parents and, consequently, the children. This is in line with Schmidt and Angonese (2009), who showed that the impact of the diagnosis of ID at a school age, during childhood, extends until adult life, influencing the individual in multiple contexts.

Parents adopted other strategies: moving their children to another school (specialized or regular), 
keeping or removing their children from school, and adjusting their work routine to ensure their children's access to school and/or therapies. Although the previously mentioned strategies (negotiation or lack of dialogue with the school) have resulted in the school's flexibility, in some cases they only led to the children's compromised acquisition of school knowledge and the existence of excluding practices at school, either from teachers or fellow classmates.

Parents who moved their children to another school achieved the following results: feeling better in the new school (specialized or regular), and changes in the parents' routines. Parents who decided to remove their children from the school without enrolling them in another educational institution focused on thinking of new alternatives for their children, such as new complementary therapies for that their children. In some instances, the results were similar, regardless of the strategy adopted by the parents, as they had to cope with the lack of flexibility in the school setting. For example, P1 and P7, although the latter had negotiated possibilities of adaptation for her daughter with the school, reported a similar result: negative impact on the acquisition of school knowledge, which is a result shared by many parents of people with disabilities attending regular schools (Maturana \& Cia, 2015; Pletsch, 2014a; Pletsch, 2014b). This situation made P7 take an even more radical strategy than negotiation - she moved her daughter to another school and, in an attempt to avoid the previous results, she worked with the directors of the new school to design a strategy that would ensure that her daughter had learning opportunities. They decided that $\mathrm{F} 7$ would be enrolled in the first year of basic education, even though she had already completed the fourth year of this level of education at her former school.

\section{Conclusion}

The GT methodology allowed for the identification of strategies adopted by parents in the process of Experiencing the schooling process of children with disabilities: between school exclusion, inclusion and integration. Furthermore, data analysis with the constant interaction between these data and the emerging concepts helped to understand how the micro and macro constraints of this phenomenon relate to each other and guide the strategies. The consequences from these strategies contribute to the phenomenon, adding new characteristics to the conditions, maintaining the existing strategies, or enabling the emergence of new ones. Additionally, understanding the dynamics inherent to the phenomenon contributes to a better understanding of the psychosocial processes involved in the enrollment of students with disabilities in school.

The conditions that make up this phenomenon make up the structure of The school world for students with disabilities. One of the main aspects in this structure is that, according to these parents' experiences, although the Objectives related to the children's quality of life are closely related to the Children's characteristics, their contribution is not isolated; on the contrary, they reinforce the perception of disability as being an individual's intrinsic characteristic, with no association with the environment.

Therefore, when proposing the interaction between the conditions (causal, intervening, and contextual), we believe that the children's characteristics, abilities, and limitations should focus not only on the diagnosis of disability (intellectual or multiple disabilities), but also on the Characteristics of the school setting, and on the Day-to-day of the children's schooling process. In other words, children's characteristics, such as the difficulty in reading and writing, which was a common concern in these parents' accounts, is not only based on the diagnosis, but also on the interaction between aspects related to the children's intellectual or multiple disabilities and the type of school or education, the school directors and teachers' attitudes towards the children's characteristics and school inclusion, etc.

This emphasis on the dynamic nature of the conditions puts into evidence the importance of the role of each social actor (teachers, school directors, parents, and students) in shaping this phenomenon based on the consequences of their actions and interactions. These open up possibilities for alternative experiences. As such, in their interventions, and regardless of their area of knowledge and activity, professionals should empower the parents of young or adult children with disabilities to recognize the power of their actions in their children's development, and expand their perceptions of the children's characteristics. This will allow parents to view their children from a dynamic perspective, one that goes beyond clinical aspects. Further studies should be conducted to discuss 
and problematize the experience of the schooling process of people with disabilities, namely from the perspective of students themselves, rather than exclusively based on their parents or teachers' experiences.

\section{References}

American Association on Intellectual and Developmental Disabilities. (2010). Intellectual disability: Definition, classification and systems of supports ( $11^{\mathrm{a}} \mathrm{ed}$.). Washington, DC: Author.

Fernandes, C. P., Vale, D. E., Nóbrega, E. B., Dias, M. M., \& Sousa, S. F. (2012). Ansiedade e necessidades dos cuidadores de crianças com e sem deficiência. Revista de Enfermagem Referência, 3(6),181-189. doi: 10.12707/RIII11106

Flick, U. (2009). Introdução à pesquisa qualitativa (3 $3^{\mathrm{a}} \mathrm{ed}$.). (J. E. Costa, Trad.). Porto Alegre, Brasil: Artmed. (Original work published 2007).

Lima, S. R., \& Mendes, E. G. (2011). Escolarização da pessoa com deficiênciaintelectual: Terminalidade específicae expectativas familiares. Revista Brasileira de Educação Especial, 17(2), 195-208. doi: 10.1590/\$1413-65382011000200003

Martins, M., \& Couto, A. P. (2014). Vivências do dia-a-dia de pais com filhos deficientes. Revista de Enfermagem Referência, 4(1), 117-124. doi: 10.12707/RIII1266

Martins, C. A., Abreu, W. J., \& Figueiredo, M. C. (2014). Tornarse pai e mãe: Um papel socialmente construído. Revista de Enfermagem Referência, 4(2), 121-131. doi: 10.12707/ RIII1394

Maturana, A. P., \& Cia, F. (2015). Educação especial e a relação família-escola: Análise da produção científica de teses e dissertações. Psicologia Escolar e Educacional, 19(2), 349358. doi: 10.1590/2175-3539/2015/0192849
Monte, F. R., \& Santos, I. B. (Coords.). (2006). Saberes e práticas da inclusão: Dificuldades acentuadas de aprendizagem: Deficiência múltipla. Brasília, Brasil: Ministério da Educação, Secretaria de Educação Especial.

Pletsch, M. D. (2014a). A escolarização de pessoas com deficiência intelectual no Brasil: Da institucionalização às políticas de inclusão (1973 à 2013). Arquivos Analíticos de Políticas Educativas, 22(1), 1-29. doi: 10.14507/epaa.v22n81.2014

Pletsch, M. D. (2014b). Educação especial e inclusão escolar: Políticas, práticas curriculares e processos de ensino e aprendizagem. Poíesis Pedagógica, 12(1), 7-26. doi: 10.5216/rpp.v12i1.31204

Rocha, M. G., \& Pletsch, M. D. (2015). Deficiência múltipla: Disputas conceituais e políticas educacionais no Brasil. Cadernos de Pesquisa, 22(1), 112-125. doi: 10.18764/21782229.v22.n1.p.112-125

Schmidt, A., \& Angonese, L. S. (2009). O adulto com deficiência intelectual: Concepção de deficiência e trajetória escolar. In Anais do IX Congresso Nacional de Educação - EDUCERE/ III Encontro Sul Brasileiro de Psicopedagogia: Políticas e práticas educativas: Desafios da aprendizagem, Paraná, Brasil, 26-29 Outubro 2009 (pp. 4293-4303). Retrieved from http://www.pucpr.br/eventos/educere/educere2009/anais/ pdf/3025_1690.pdf

Silveira, F. F., \& Neves, M. M. (2006). Inclusão escolar de crianças com deficiência múltipla: Concepções de pais e professores. Psicologia: Teoria e Pesquisa, 22(1), 79-88. doi: 10.1590/ S0102-37722006000100010

Strauss, A., \& Corbin, J. (2008). Pesquisa qualitativa: Técnicas e procedimentos para o desenvolvimento de teoria fundamentada ( $2^{\mathrm{a}} \mathrm{ed}$.). (L. O. Rocha, Trad.). Porto Alegre, Brasil: Artmed. (Original work published 1998).

Verdugo, M. A., \& Jenaro, C. (2014). Características clínicas e tratamento da deficiência mental. In V. E. Caballo \& M. A. Simón (Orgs.), Manual de psicologia clínica infantil e do adolescente: Transtornos gerais. (S. M. Dolinsky, Trad.). São Paulo, Brasil: Santos. (Obra original publicada em 2001). 
